\title{
PENINGKATAN AKTIVITAS DAN HASIL BELAJAR SISWA \\ MELALUI PENERAPAN MODEL LEARNING CYCLE 7E (LC 7E) \\ PADA PEMBELAJARAN BIOLOGI KELAS X IPA 4 SMA NEGERI 1 \\ BRINGIN TAHUN PELAJARAN 2016/2017
}

\author{
Mita Mirjanah'), Susanti Pudji Hastuti²), dan Desy Fajar Priyayi ${ }^{\text {3) }}$ \\ ${ }^{1}$ Mahasiswa Sarjana Pendidikan Biologi Universitas Kristen Satya Wacana \\ ${ }^{2}$ Dosen Jurusan Biologi Universitas Kristen Satya Wacana \\ ${ }^{3}$ Dosen Jurusan Pendidikan Biologi Universitas Kristen Satya Wacana \\ mitametet@gmail.com
}

\begin{abstract}
The purpose of this study is to improve learning activities and cognitive learning results by applying the learning cycle $7 E(L C 7 E)$ in the ecosystem concept. This study was done in SMA Negeri 1 Bringin by using the students from Class $X$ IPA 4 as the subjects. The method applied in this study is the descriptive analysis method with the data collection instruments such as questionnaires, observation sheets, interview and test. Based on the result of students learning activities in cycle I, students who have good category of learning activities is $62,5 \%$. In cycle II students who have good category increased to $93,75 \%$ and very good category is $6,25 \%$. Based on the students' cognitive learning outcome, the students' that fulfilling the minimum criteria (KKM) in cycle I is $43,75 \%$ and incrased to $100 \%$ in cycle II. Based on the results of gain score analysis in cycle I, student with the high category is $43,75 \%$, medium category is $21,88 \%$, and low category is $34,38 \%$. Then, in cycle II student with the high category is $81,25 \%$, medium category is $12,50 \%$, and low category is $6,25 \%$. The result show that the application of LC 7E models can make students become more active in learning. Learning activities can facilitate students to understand the concept so that it improve students learning outcome.
\end{abstract}

Keywords: earning activities, learning outcome, LC 7E, gain score

\begin{abstract}
Abstrak. Tujuan dari penelitian ini adalah untuk meningkatkan aktivitas dan hasil belajar kognitif siswa melalui model pembelajaran Learning cycle 7E dalam materi komponen ekosistem. Penelitian ini dilakukan di SMA Negeri 1 Bringin dengan menggunakan siswa kelas X IPA 4sebagai subyek. Metode yang digunakan dalam penelitian ini adalah analisis deskriptif dengan instrumen pengumpulan datanya berupa angket, lembar observasi, wawancara dan tes. Berdasarkan hasil penelitian, pada siklus I siswa yang memiliki aktivitas belajar kategori baik sebesar 62,5\%. Pada siklus II aktivitas belajar kategori baik meningkat menjadi 93,75\% dan aktivtias belajar kategori sangat baik sebesar 6,25\%. Berdasarkan hasil belajar kognitif siswa, persentase siswa yang memenuhi KKM 70 pada siklus I sebesar $43,75 \%$ meningkat menjadi $100 \%$. Berdasarkan hasil analisis gain score, pada siklus I siswa yang termasuk dalam kategori tinggi sebesar 43,75\%, kategori sedang sebesar 21,88\% dan kategori rendah sebesar 34,38\%. Pada siklus II siswa yang termasuk kategori tinggi sebesar $81,25 \%$, kategori sedang sebesar $12,50 \%$ dan kategori rendah sebesar 6,25\%. Hasil penelitian menunjukkan bahwa penerapan model LC 7E mampu membuat siswa lebih aktif dalam proses pembelajaran. Melalui aktivitas belajar yang dilakukan
\end{abstract}


siswa lebih mudah untuk memahami dan mengingat konsep materi sehingga hasil belajar kognitif siswa meningkat.

Kata kunci: aktivitas belajar, gainscore, hasil belajar, LC 7E,

\section{Pendahuluan}

Pembaharuan dalam bidang pendidikan harus selalu dilakukan guna untuk meningkatkan kualitas pendidikan nasional, baik dalam pembaharuan kurikulum, peningkatan kualitas pembelajaran, dan keefektifan metode pembelajaran (Nurhadi, 2004). Salah satu pembaharuan tersebut adalah penerapan kurikulum. Kurikulum yang digunakan saat ini diantaranya yaitu kurikulum 2013.Kurikulum 2013menyatakan perlu adanya peningkatan dan keseimbangan aspek sikap, keterampilan, dan pengetahuan. Proses pembelajaran yang semula berfokus pada eksplorasi, elaborasi, dan konfirmasi dituntut lebih lagi dilengkapi dengan aspek mengamati, menanya, mengolah, menalar, menyajikan, menyimpulkan, dan mencipta. Guru bukan merupakan satu-satunya sumber belajar. Guru sebagai pengajar merupakan pencipta kondisi belajar siswa yang didesain secara sengaja, sistematis, dan berkesinambungan. Mukaromah dkk (2012) menyatakan bahwa siswa sebagai subjek pembelajaran merupakan pihak yang menikmati kondisi belajar yang diciptakan guru. Kegiatan belajar mengajar harus merupakan aktivitas yang hidup, sarat nilai dan senantiasa memiliki tujuan (Fathurrohman dan Sutikno 2009).

Keaktifan peserta didik merupakan hal yang sangat penting dan perlu diperhatikan oleh guru. Guru diharapkan dapat merancang pembelajaran yang berorientasi pada aktivitas belajar siswa. Proses pembelajaran yang berlangsung diharapkan dapat memberi kesempatan kepada siswa untuk berhipotesis sendiri, mencari cara pemecahan masalah yang mereka hadapi dengan pengalaman sendiri sehingga siswa mampu membangun konsep pembelajaran sendiri. Aktivitas belajar merupakan seluruh tindakan yang sengaja dirancang oleh guru untuk memfasilitasi kegiatan belajar siswa seperti kegiatan diskusi, demonstrasi, simulasi, melakukan percobaan dan lain sebagainya (Sanjaya, 2006). Dengan demikian, aktivitas belajar dapat diartikan sebagai keseluruhan kegiatan siswa yang merupakan wujud dari usaha mereka untuk mencapai hasil belajar yang diinginkan. Menurut Paul D. Diedrich dalam Hamalik (2004) aktivitas belajar digolongkan menjadi 8kelompok yaitu Visual Activities, Oral Activities, Listening Activities, Writting Activities, Drawing Activities, Motor Activities, Mental activities, dan Emotional Activities. Aktivitas belajar siswa selama proses pembelajaran merupakan salah satu indikator adanya keinginan siswa untuk belajar (Hamalik, 2009). Aktivitas belajar siswa mempunyai hubungan yang erat dengan kemampuan kognitif siswa. Kemampuan kognitif siswa didapatkan melalui aktivitas belajar yang mereka lakukan sebelumnya (Rachman, 2013). Semakin tinggi tingkat aktivitas belajarnya maka siswa tersebut dapat memperoleh kemampuan kognitif yang tinggi pula (Kursiyati, 2011). Salah satu cara untuk meningkatkan kemampuan kognitif siswa yang tinggi adalah dengan meningkatkan aktivitas belajarnya. Hal ini berlaku pada semua mata pelajaran, termasuk biologi.

Pembelajaran Biologi bertujuan untuk meningkatkan pengetahuan, pemahaman konsep, sikap, nilai dan tanggungjawab sebagai manusia dalam lingkungan masyarakat, serta sejumlah kemampuan sebagai bekal memasuki jenjang pendidikan yang lebih tinggi.Pembelajaran biologi khususnya di Sekolah Menengah Atas (SMA) perlu diarahkan ke berbagai bentuk aktivitas belajar siswa. Pembelajaran dirancang sedemikian hingga siswa aktif dan terampil 
dalam menganalisis fenomena yang terjadi di lingkungan sekitar menggunakan konsep materi biologi. Model yang melibatkan banyak aktivitas siswa ketika pembelajaran salah satunya adalah model pembelajaran yang berbasis kontruktivis, dimana siswa membangun pemikirannya sendiri mulai dari bagaimana mereka memecahkan masalah, mecari sumber - sumber yang relevan, sampai bagaimana mengolah informasi yang mereka dapatkan sehingga banyak aktivitas belajar yang berlangsung nantinya.

Berdasarkan observasi awal serta wawancara dengan guru biologi dan siswa yang telah dilakukan di SMANegeri 1 Bringin, proses pembelajaran yang telah dilakukan selama ini menggunakan metode ceramah dan diskusi. Berdasarkan hasil observasi dan analisis aktivitas belajar, sebanyak 81,25\% siswa termasuk dalam kategori kurang, dan sebanyak 18,75\% termasuk dalam kategori sangat kurang. Aktivitas belajar dilihat berdasarkan kegiatan siswa selama proses pembelajaran berlangsung. Siswa masih sebatas hanya mendengarkan penjelasan dari guru. Siswa enggan mencari sumbersumber yang terkait materi pembelajaran. Beberapa siswa mencatat hanya ketika diperintah guru. Siswa cenderung pasif dalam hal bertanya, baik bertanya kepada guru maupun kepada temannya. Kurangnya aktivitas belajar memberikan dampak terhadap rendahnya hasil kognitif siswa. Hasil kognitif rendah didukung oleh data nilai Ulangan Harian (UH) dan Ulangan Tengah Semester (UTS) siswa kelas X IPA 4 dengan siswa yang tuntas mencapai $50 \%$, rendahnya persentase tersebut menunjukkan bahwa masih kurang dipenuhinya indikator - indikator yang menjadi tujuan dalam pembelajaran. Rendahnya aktivitas dan hasil belajar menunjukkan proses pembelajaran yang kurang efektif dan efisien. Hal tersebut menunjukkan perlu adanya perbaikan baik pada tahap perencanaan maupun pelaksanaan pembelajaran.Gurusebagai pengajar yang kreatif perlu menerapkan model pembelajaran yang inovatif. Salah satu model yang digunakan untuk meningkatkan aktivitas dan hasil belajar kognitif siswa adalah learning cycle 7E (LC 7E).

Model pembelajaranLC 7E merupakan salah satu tipe model pembelajaran berbasis kontruktivisme (Sumiyati dkk, 2016). Pengetahuan dibangun berdasarkan hasil pemikiran siswa. Siswa dituntut aktif dalam pembelajaran melalui tahapan - tahapan yang disusun oleh guru sedemikian rupa sehingga siswa dapat menguasai materi secara mandiri. Menurut Eisenkraft (2003) model learning cycle 7E terdiri atas tujuh tahap/fase yang saling terkait yaitu elicit (memperoleh), engage (pembangkitan minat), explore (eksplorasi), explain (menjelaskan), elaborate (elaborasi), evaluate (evaluasi), dan extend (mengembangkan). Model pembelajaran learning cycle $7 \mathrm{E}$ memiliki kelebihan antara lain merangsang siswa untuk mengingat kembali materi pelajaran yang telah mereka dapatkan sebelumnya, memberikan motivasi kepada siswa untuk menjadi lebih aktif dan menambah rasa ingin tahu siswa, melatih siswa belajar menemukan konsep melalui eksperimen, melatih siswa untuk menyampaikan secara lisan konsep yang telah mereka pelajari, memberikan kesempatan kepada siswa untuk berpikir, mencari, menemukan dan menjelaskan contoh penerapan konsep yang telah dipelajari (Sutrisno dkk, 2012).

Model pembelajaran LC 7E merupakan model yang mengajak siswa untuk menemukan sendiri konsep dalam pembelajaran. Kegiatan di dalam model LC 7E melibatkan banyak aktivitas belajar siswa seperti mengamati fenomena yang terjadi disekitar, mendengarkan teman berdiskusi, menemukan konsep sendiri, melakukan demonstrasi, serta mendorong siswa untuk berani mengungkapkan hasil temuannya.

Penelitian ini bertujuan untuk mengetahui peningkatan aktivitas dan hasil belajar kognitif siswa melalui penerapan model LC $7 \mathrm{E}$. 


\section{Metode}

Jenis penelitian ini merupakan Penelitian Tindakan Kelas (PTK), dengan masing- masing tahap yaitu, perencanaan, ppelaksanaan, pengamatan, refleksi. Penelitian dilaksanakan di kelas X IPA 4 SMA Negeri 1 Bringin yang beralamat di Jl. Wibisono Gang II No. 3, Bringin, Kabupaten Semarang pada semester II tahun pelajaran 2016/2017. Subyek dalam penelitian ini adalah seluruh siswa kelas X IPA 4 SMA Negeri 1 Bringin dengan jumlah 32 siswa, terdiri dari 6 siswa laki - laki dan 26 siswa perempuan. Teknik pengumpulan data dilakukan dengan menggunakan lembar observasi (LO), angket, wawancara dan tes. Target penelitian ini 85\% siswamencapai nilai KKM 70 dan 85\% siswa memperoleh aktivitas belajar kategori baik atau sangat baik.

Analisis data dilakukan dengan analisis deskriptif. Untuk menganalisis data hasil belajar kognitif digunakan rumus :

Nilai tes kognitif $=$

Jumlah skor yang diperoleh siswa Jumlah skor maksimal $\times 100$

Persentase ketuntasan $(\%)=$

$$
\frac{\text { JumlahsiswayangtuntasKKM }}{\text { Jumlahtotalsiswa }} \times 100 \%
$$

Kemudian data nilai prettest dan posttest dianalisis dengan menggunakan rumus gain score. Gain score menunjukkan peningkatan hasil belajar setelah siswa mengalami proses pembelajaran ( Hake, 1999).

$$
\mathrm{g}=\frac{S f-S i}{S \max -S i}
$$

Keterangan :

$$
\begin{array}{ll}
\mathrm{g} & =\text { gain score } \\
\mathrm{Sf} & =\text { nilai posttest } \\
\mathrm{Si} & =\text { nilai pretest } \\
\mathrm{Smax} & =\text { nilai maksimum }
\end{array}
$$

Hasil perhitungan gain score yang telah diperoleh selanjutnya dikategorikan sesuai dengan kategori yang dapat dilihat pada Tabel 2.1.

Tabel 1. Kategori gain score

\begin{tabular}{cc}
\hline Rentang & Kategori \\
\hline $0,7<\mathrm{g} \leq 1,0$ & Tinggi \\
$0,3<\mathrm{g} \leq 0,7$ & Sedang \\
$0,00<\mathrm{g} \leq 0,3$ & Rendah \\
\hline
\end{tabular}

Untuk analisis data aktivitas belajar siswa digunakan rumus :

Rata-rata tiap siswa $=$

$$
\frac{\text { Jumlah skor yang diperoleh }}{\text { Jumlah skor maksimal }}
$$

Rata-rata kelas $=$

$$
\frac{\text { jumlahrata }- \text { ratasiswa }}{\text { Jumlahtotalsiswa }}
$$

Kemudian nilai siswa dihitung secara individu dan dikategorikan menjadi empat kategori yaitu kurang, cukup, baik, dan sangat baik sesuai dengan Tabel 2.2.Interval kategori dihitung dengan rumus:

Interval $=$

$$
\frac{\text { Nilai maksimal - nilai minimal }}{\text { Jumlahkategori }}
$$

Tabel 2. KategoriNilai Aktivitas Belajar Siswa

\begin{tabular}{cc}
\hline Nilai & Kategori \\
\hline $46-56$ & Sangat baik \\
$35-45$ & Baik \\
$24-34$ & Kurang \\
$13-23$ & Sangat Kurang \\
\hline
\end{tabular}

(Widoyoko, 2009)

\section{Hasil dan Pembahasan}

\section{A. Hasil Penelitian \\ 1. Hasil Aktvitas Belajar siswa}

Berdasarkan hasil penelitian tindakan kelas dengan model learning cycle 7E (LC 
7E) selama dua siklus diperoleh nilai aktivitas belajar siswa yang ditunjukkan oleh Gambar 2. dan Tabel 3

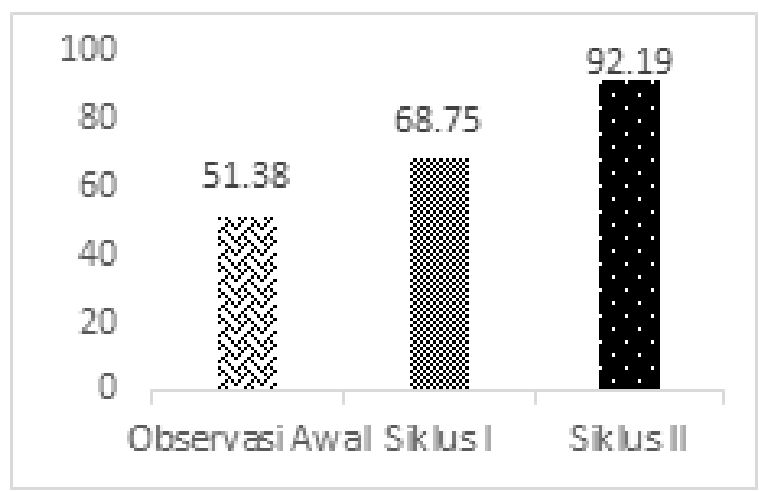

Gambar 2. Rata-rata nilai aktivitas belajar siswa

Tabel 3. Kategori Nilai Aktivitas Belajar Siswa

\begin{tabular}{cccc}
\hline Kategori & $\begin{array}{c}\text { Observasi } \\
\text { awal (\%) }\end{array}$ & $\begin{array}{c}\text { Siklus I } \\
(\mathbf{\%})\end{array}$ & $\begin{array}{c}\text { Sikllus II } \\
\mathbf{( \% )}\end{array}$ \\
\hline Sangat baik & & & 6,25 \\
Baik & & 62,5 & 93,75 \\
Kurang & 81,25 & 37,5 & \\
Sangat & 18,75 & & \\
kurang & & & \\
\hline
\end{tabular}

\section{Hasil Belajar Kognitif}

Berdasarkan hasil penlitian yang telah dilakukan selama dua siklus, diperoleh data hasil belajar kognitif yang ditunjukkan pada Gambar 3 dan Gambar 4.

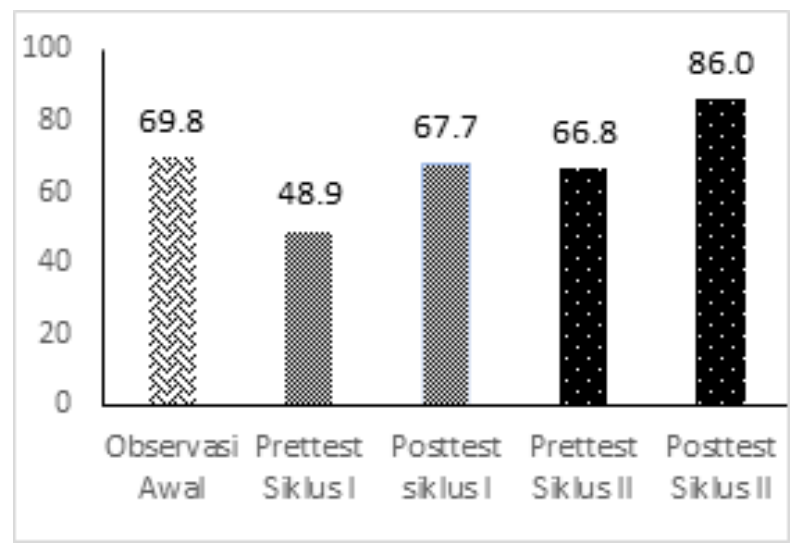

Gambar 3.Rata-rata nilai kognitif

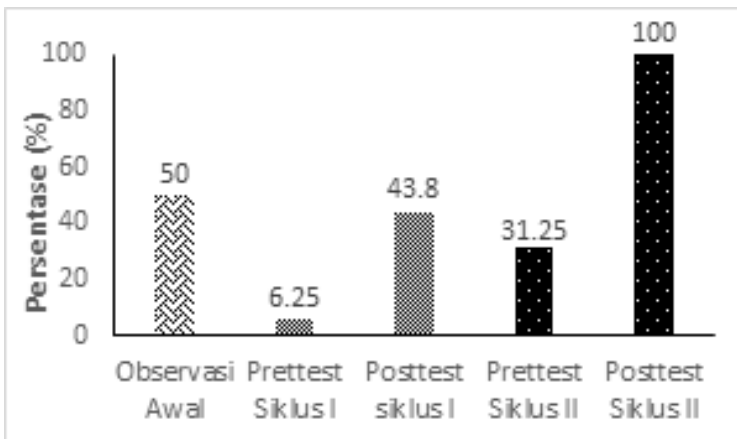

Gambar 4. Ketuntasan klasikal nilai tes kognitif

Tabel 4. Kategori Nilai Gain score

\begin{tabular}{ccc}
\hline Kategori & Siklus I (\%) & Siklus II (\%) \\
\hline Tinggi & 43,75 & 81,25 \\
Sedang & 21,88 & 12,50 \\
Rendah & 34,38 & 6,25 \\
\hline
\end{tabular}

3. Keterlaksanaan model LC 7E

Berdasarkan keterlaksanaan langkahlangkah model LC 7E sesuai dengan Rencana Pelaksanaan Pembelajaran (RPP) didapatkan hasil yang dtunjukkan oleh gambar 5 .

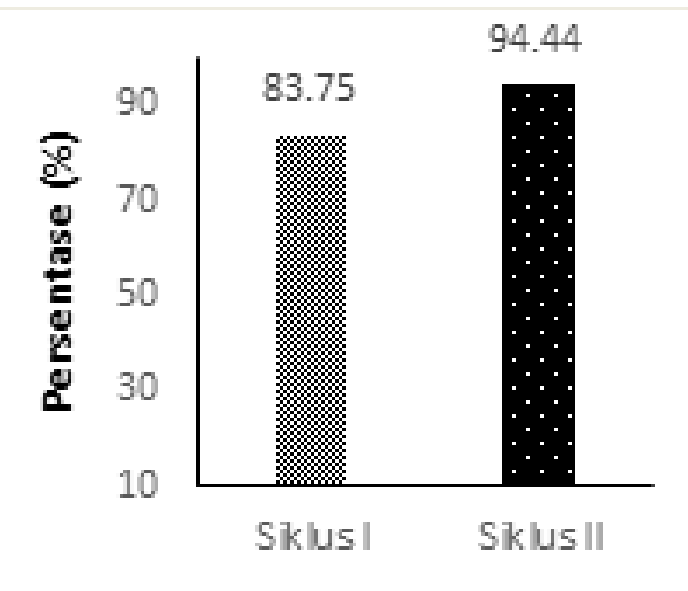

Gambar 5. Persentase keterlaksanaan pembelajaran menggunakan model LC 7E

B. Pembahasan

1. Deskripsi Siklus

Siklus PTK terdiri atas tahap perencanaan, pelaksanaan, pengamatan, dan refleksiPada tahap perencanaan guru dan 
peneliti melakukan penyusunan rencana pelaksanaan pembelajaran (RPP), lembar kerja siswa (LKS), soal, lembar observasi (LO) aktivitas, lembar observassi (LO) keterlaksanaan, dan angket aktivitas. Selanjutnya pada tahap pelaksanaanguru menerapkan RPP menggunakan model LC 7E sekaligus dilakukan pengamatan oleh observer. Pada tahap elicit guru memberikan pertanyaan- pertanyaan yang merangsang pengetahuan awal siswa agar timbul respon dari pemikiran siswa serta menimbulkan rasa ingin tahu tentang jawaban dari pertanyaanpertanyaan yang diajukan oleh guru. Tahap engage digunakan untuk memfokuskan perhatian siswa, merangsang kemampuan berpikir serta membangkitkan minat dan motivasi siswa terhadap pelajaran biologi atau konsep yang akan diajarkan. Tahap explore memberikan kesempatan kepada siswa untuk memanfaatkan panca indera mereka semaksimal mungkin dalam berinteraksi dengan lingkungan melalui kegiatan pengamatan dan telaah literatur. Tahap explain memberikan kesempatanyang luas kepada siswa untuk menyampaikan ide atau gagasan yang mereka miliki melalui kegiatan diskusi dan presentasi. Tahap elaborate mengajak siswa mengaplikasikan konsep-konsep yang mereka dapatkan dengan mengerjakan soal-soal pemecahan masalah dan terdapat suatu tes akhir untuk mengetahui sejauh mana tingkat pemahaman siswa terhadap konsep yang telah dipelajari (evaluate).Tahapextend melatih siswa untuk dapat menemukan dan menjelaskan contoh penerapan konsep serta mencari hubungan konsep yang dipelajari dengan konsep lain yang sudah atau belum mereka pelajari.

Berdasarkan hasil refleksi pada siklus I guru dan siswa masih mencoba beradaptasi dengan model baru yang belum pernah digunakan. Penggunaan model pembelajaran LC 7E belum terlaksana dengan baik, masih terdapat kekurangan yang harus diperbaiki. Pada tahap awal pembelajaran guru kurang menjelaskan langkah-langkah pembelajaran secara rinci, sehingga siswa masih bingung dan banyak bertanya kepada guru. Ketika proses diskusi mengenai pengamatan ekosistem di lingkungan sekolah guru masih belum bisa memaksimalkan perannya sebagai fasilitator. Selain itu, siswa masih kurang aktif dalam mencari informasi dan menggunakan berbagai sumber yang relevan untuk mencari jawaban atas pertanyaan yang diberikan. Siswa yang menggunakan internet dan buku sebagai sumber hanya 71,88\% siswa. Saat presentasi hasil diskusi dilakukan oleh kelompok siswa, guru telah memberikan masukan serta konfirmasi, namun siswa kelompok lain tidak memperhatikan. Alokasi waktu pelaksanaan siklus 1 juga melebihi dari perencanaan. Berdasarkan hasil refleksi yang dilakukan, pada siklus I ini masih terdapat kekurangan sehingga perlu adanya perbaikan untuk dilakukan pada siklus berikutnya.

Berdasarkan hasil refleksi pada siklus I maka perbaikan dlakukan pada siklus II. Hasil refleksi siklus II yaitu guru lebih rinci lagi dalam menyampaikan tujuan, prosedur pembelajaran, termasuk alokasi waktu.Siswa segera mengerjakan permasalahan tanpa banyak bertanya lagi mengenai prosedur. Terlihat adanya peningkatan kinerja guru dalam memfasilitasi siswa selama diskusi pada sklus II, guru berkeliling ke setiap kelompok untuk membantu ketika siswa menemukan kesulitan dan mendorong siswa untuk menggunakan berbagai sumber dalam menemukan solusi permasalahan. Oleh karena itu, siswa dapat berkerja dengan cepat dan lebih teliti sehingga selesai tepat waktu. Saat dan setelah penyampaian hasil diskusi dilakukan, guru terlibat lebih aktif dalam mengkonfirmasihasildiskusisiswa.Kemudian setelah proses presentasi dan konfirmasi guru memberikan permasalah kembali kepada siswa yang nantinya siswa harus berdiskusi kembali dengan menggunakan berbagai sumber dalam pemecahan permasalahannya tersebut. Masalah yang dijumpai siswa pada siklus I dapat diatasi pada siklus II. Siswa sudah mengerti bahwa siswa juga harus paham mengenai materi yang berkaitan dengan permasalahan agar dapat memberikan 
penyelesaian atau solusi. Oleh karena itu, pada siklus II siswa menggunakan macam macam sumber belajar baik dari buku maupun internet dalam mempelajari permasalahan daur biogeokimia dan membuat solusi.

\section{Peningkatan Aktivitas Belajar Siswa melalui Penerapan Model LC 7E}

Model pembelajaran LC 7E merupakan rangkaian tahap kegiatan yang diorganisasi sedemikian rupa sehingga siswa dapat menguasai kompetensi yang harus dicapai dalam pembelajaran dengan jalan berperan aktif.Pembelajaran dengan menggunakan model siklus belajar LC 7E menuntut siswa aktif karena di dalam tahapantahapan model ini setiap tahapannya melibatkan siswa sepenuhnya. Melalui model LC 7E siswa akan banyak melakukan aktivitas seperti kegiatan tanya jawab, berdiskusi, melakukan pengamatan, memecahkan masalahmemberikan pendapat, mempresentasikan di depan kelas dan menyimpulkan atau melakukan 8 kategori aktvitas menurut Paul D Dierich. Dengan kegiatan- kegiatan yang ada dalam tahapan model pembelajaran siklus belajar $7 \mathrm{E}$ dapat berpengaruh dalam meningkatkan aktivitas dan hasil belajar siswa sehingga pembelajaran menjadi bermakna bagi siswa karena siswa mengalaminya secara langsung.

Keaktifan peserta didik dalam proses pembelajaran merupakan hal yang penting dan perlu diperhatikan oleh guru. Untuk meningkatkan aktivitas dan hasil belajar siswa upaya yang dilakukan adalah dengan menggunakan model pembelajaran kontruktivisme yaitu LC 7E (Sumiyati dkk, 2016).Berdasarkan hasil observasi yang telah dilakukan menggunakan LO aktivitas selama proses pembelajaran menggunakan model LC 7E pada siklus I dan siklus II mengalami peningkatan pada setiap siklusnya. Perbandingan peningkatan aktivitas siswa pada pelaksanaan pembelajaran yang dilakukan sebanyak dua siklus dapat dilihat pada Gambar 3.1 serta peningkatan pada tiap aspeknya dapat dilihat pada Gambar 3.2.
Kegiatan aktivitas belajar yang dinilai diantaranya sebagai berikut: Visual activities, dalam pembelajaran LC 7E siswa diberikan kesempatan untuk membaca materi, mencari jawaban - jawaban dari permasalahan yang diberikan, mencari sumber untuk digunakan sebagai acuan dalam mengerjakan lembar kerja siswa. Menurut Mayliana dkk (2013) Pembelajaran visual menurut beberapa ahli lebih kuat melekat pada memori manusia disebabkan manusia lebih banyak peralatan dikepala untuk memproses informasi visual dibandingkan indera yang lain.Pembelajaran dengan visual mencakup dalam melihat, menciptakan dan mengintegrasikan segala macam citra, secara ilmiah dikatakan bahwa komunikasi visual lebih kuat karena manusia mempunyai lebih banyak peralatan di kepala mereka untuk memproses informasi visual daripada inderalainnya (Meier, 2004). Berdasarkan hasil yang didapat aktivitas visual siswa meningkat secara signifikan, hal ini terjadi karena pada aspek visual aktivitas yang dilakukan adalah siswa diberi tugas dengan cara membaca, mencari sumbersumber yang relevan sehingga hal tersebut dapat meningkatkan pengetahuan siswa.

Oral activities, dalam pembelajaran LC 7E siswa diberikan kesempatan untuk bertanya tentanghal-hal yang kurang dipahami, menjawab pertanyaan - pertanyaan yang di lontarkan oleh guru ataupun temannya sendiri, serta dapat memberikan pendapat meraka saat diskusi berlangsung atau ketika dalam mengerjakan langkah pengamatan. Listening activities, dalam pembelajaran siswa mendengarkan penjelasan dari guru dan mendengarkan teman yang sedang menjelaskan hasil diskusi/presentasi.Secara ilmiah dapat diterangkan bahwa, ketika si pembelajar berbicara keras-keras tentang apa yang sedang mereka pelajari, itu merangsang korteks (selaput otak) indra dan motor (serta area otak lainnya) untuk memadatkan dan mengintegrasikan pembelajaran (Meier, 2004).

Writing activities, menullis merupakan aktivitas sederhana yang dapat membuat 
seseorang menyampaikan ide, gagasan, membangun pemahaman, serta melatih kemampuan berpikir (Dispriyani dkk, 2015). Dalam pembelajaran LC 7E siswa diberikan kesempatan untuk mencatat materi, mencatat hasil diskusi, mengerjakan tugas - tugas yang diberikan secara tulisan. Drawing activities, dalam pembelajaran siswa diberikan kesempatan untuk menggambar skema pada LKS, siswa membuat gambar bersama dengan kelompok, menggambar skema atau mind map pada buku catatan agar dapat lebih mudah memahami materi yang sedang dipelajari.

Motor activities, dalam pembelajaran LC 7E siswa diajak untuk melakukan pengamatan di lungkungan sekitar, kemudian melakukan diskusi. Kegiatan diskusi dilakukan secara berkelompok dimana kegiatan belajar secara berkelompok akan memperluas pengetahuan siswa. Karena ketika berkelompok siswa berinteraksi dengan anggota lainnya, sehingga pertukaran informasi akan berlangsung (Mustari dkk, 2016).

Mental activities, dalam pembelajaran LC 7E siswa dapat menyelesaikan suatu permasalahan, serta mengingat materi yang sudah dipelajari. Emotional activities, dalam pembelajaran siswa merasa bersemangat, berani dan percaya diri ketika melakukan presentasi di depan kelas.Berdasarkan indikator tersebut siswa dikatakan aktif apabila siswa melakukan keaktifan oral, visual, listening, writing, drawing, mental, emotionalnya.

\section{Peningkatan Hasil Belajar Kognitif Siswa melalui Penerapan Model LC 7E}

Peningkatan hasil belajar ditandai dengan nilai hasil belajar siswa yang meningkat. Peningkatan hasil belajar siswa dalam pembelajaran dilihat dari bagaimana siswa mengikuti pembelajaran atau siswa lebih memahami materi yang disajikan oleh guru (Mayliana dkk, 2013). Hasil belajar diperoleh dari hasil evaluasi yang diberikan di akhir pembelajaran dengan tujuan untuk mengetahui sejauhmana pemahaman siswa setelah mengikuti proses pembelajaran. Aktivitas siswa selama proses pembelajaran tentunya akan mempengaruhi terhadap hasil akhir yang di dapat oleh siswa. Kursiyati (2011) menyatakan bahwa semakin tinggi tingkat aktivitas belajarnya maka siswa tersebut dapat memperoleh kemampuan kognitif yang tinggi pula. Salah satu cara untuk meningkatkan kemampuan kognitif siswa yang tinggi adalah dengan meningkatkan aktivitas belajarnya.

Hasil belajar kognitif diukur menggunakan soal prettest dan soal evaluasi dalam bentuk uraian untuk prettest dan pilihan ganda untuk evaluasi dengan tingkat kesulitan soal mulai C1-C6. Target penelitian hasil belajar kognitif adalah siswa tuntas KKM yaitu 70 secara klasikal $85 \%$ siswa. Hasil belajar kognitif siswa meningkat pada setiap siklusnya. Peningkatan yang cukup signifikan terjadi antara siklus I dan siklus II, dilihat berdasarkan hasil rata - rata $N$-gain pada siklus I 0,80 atau $2.51 \%$ dalam kategori Tinggi kemudian pada siklus II rata - rata $N$-gainmeningkat menjadi 1,39 atau 4,35\% dalam kategori tinggi. Dari hasil ketuntasan klasikal dapat diketahui model pembelajaran LC 7E dapat meningkatkan hasil belajar kognitif siswa dari yang awalnya 50\% siswa tuntas kemudian pada siklus I menjadi $43,75 \%$ dan pada siklus II meningkat menjadi $100 \%$.

Melalui model LC 7E guru membantu siswa belajar dengan menggunakan lebih dari satu indra. Pada pembelajaran guru hanya memberikan materi tambahan tidak sepenuhnya menyampaikan materi dari awal sampai akhir tetapi siswa yang ditujukan untuk menemukan sendiri konsep materi yang dipelajari baik melalui proses pengamatan, pencarian dari berbagai sumber yang relevan, maupun diskusi secara kelompok. Melalui tahap-tahap model siklus belajar 7E, siswa dibimbing dan diarahkan untuk memulai aktivitas dengan memanfaatkan pengetahuan awal siswa, melakukan pengamatan untuk membangun dasar pengetahuan siswa, 
mengajukan hipotesis sebelum eksperimen, melakukan eksperimen, dan diakhiri dengan menarik kesimpulan serta menghubungkan konsep yang dipelajari dengan konsep lain. Pada aktivitas tersebut siswa akan mengalami sendiri hakikat dari pembelajaran biologi yaitu sebagai suatu proses penemuan dan sebagai suatu produk. Pengalaman belajar yang diperoleh siswa dalam tiap tahap model siklus belajar 7E lebih menekankan pada learning by doing, dengan mengadakan kontak atau interaksi langsung dengan objek yang dipelajari maka siswa akan mengalami pembelajaran menyenangkan (joyfull learning) yang berdampak pada informasi yang didapat lebih mudah diingat dan dimaknai (Dewi, 2012). Peningkatan signifikan terjadi karena penerapan model LC 7E merupakan model yang diterapkan dengan melibatkan kejadian dalam kehidupan nyata siswa, dimana tugas - tugas serta permasalahan yang diberikan guru merupakan salah satu kegiatan yang mendorong siswa untuk melakukan penyelidikan atau pengamatan langsung yang mereka lakukan sendiri. Berdasarkan penelitian yang dilakukan Afandi dkk (2016) model LC 7E lebih menekankan pentingnya memunculkan pemahaman awal siswa dan memperluas (transfer) konsep. Sehingga siswa dapat menguasai kompetensi-kompetensi yang harus dicapai dalam pembelajaran karena siswa diberikan kesempatan membangun pengetahuan dan pengalaman mereka sendiri dengan terlibat secara aktif mempelajari materi dengan bekerja dan berpikir baik secara individu maupun kelompok.

\section{Kesimpulan dan Saran}

Berdasarkan hasil penelitian dapat disimpulkan bahwa aktivitas belajar dan hasil belajar kognitif siswa mengalami peningkatan pada pembelajaran komponen ekosistem dengan menggunakan model Learning Cycle (LC 7E). Hal tersebut ditunjukkan dengan meningkatnya aktivitas siswa dari observasi awal sampai siklus II, pada siklus I siswa yang memiliki aktivitas belajar kategori baik sebesar 62,5\%. Pada siklus II aktivitas belajar kategori baik meningkat menjadi 93,75\% dan aktivtias belajar kategori sangat baik sebesar $6,25 \%$.Berdasarkan hasil belajar kognitif siswa, persentase siswa yang memenuhi KKM 70 pada siklus I sebesar 43,75\% meningkat menjadi $100 \%$ dan analisis gain score menunjukkan bahwapada siklus I siswa yang termasuk dalam kategori tinggi sebesar $43,75 \%$, kategori sedang sebesar $21,88 \%$ dan kategori rendah sebesar $34,38 \%$. Pada siklus II siswa yang termasuk kategori tinggi sebesar $81,25 \%$, kategori sedang sebesar $12,50 \%$ dan kategori rendah sebesar 6,25\%.Hasil penelitian menunjukkan bahwa penerapan model LC 7E mampu membuat siswa lebih aktif dalam proses pembelajaran. Melalui aktivitas belajar yang dilakukan siswa lebih mudah untuk memahami dan mengingat konsep materi sehingga hasil belajar kognitif siswa meningkat.

\section{Daftar Pustaka}

Afandi, R. R., Sundari., Hamid. (2016). Penerapan Model Siklus Belajar (LEARNING CYCLE) 7E Untuk Meningkatkan Hasil Belajar Siswa Dalam Pembelajaran IPS Di SD. Antologi UPI Edisi No. Juni 2016

Arikunto, S. (2010). Penelitian Tindakan Kelas. Jakarta: Bumi Aksara.

Badan Standar Nasional Pendidikan (BSNP). (2006). Panduan Kurikulum Tingkat Satuan Pendidikan. BSNP: Jakarta.

Dewi, Ni Putu. (2012). Pengaruh Model Siklus Belajar 7E Terhadap Pemahaman Konsep Dan Keterampilan Proses Siswa SMA Negeri 1 Sawan. Artikel Tesis Program Studi Pendidikan IPA Program Pascasarjana Universitas Pendidikan Ganesha Juli 2012 
Dispriyani, Novita., Ramli., Nurmiyati., Sumarjiyana. (2015). Meningkatkan scientific writing skill siswa pada pembelajaran biologi kelas X mia 7 sma n 4 surakarta menggunakan guided inquiry learning dipadu reading assigment. BIOEDUKASI: Volume 8 No 2

Eisenkraft, A. (2003). Expanding the 5 E Model A purposed 7 E model emphasizes "transfer of learning" and the importance of eliciting prior understanding.Published by the National Science Teachers Association, 1840 Wilson Blvd., Arlington, VA 22201-3000.

Fathurrohman., Sutikno. (2009). Strategi Belajar Mengajar Melalui Penanaman Konsep Umum \& Konsep Islami. Bandung: Refika Aditama.

Hake, RR. (1999). “Analyzing Change/Gain Scores". AERA-D-Amercan Educational Research Association's Division, Measurment and Research Methodology.

Hamalik, O. (2009). Kurikulum dan pembelajaran. Bumi Aksara. Jakarta: x + 184 hlm.

Hamalik, O. (2004). Proses Belajar Mengajar. Bumi aksara. Jakarta: ix + 242 hlm.

Kursiyati, U. (2011). Hubungan antara perhatian orangtua, sikap, dan aktivitas belajar dengan prestasi belajar matematika kelas VIII sekolah menengah pertama negeri 1 gadingrejo kabupaten pringsewu. Tesis Program Pasca Sarjana Teknologi Pendidikan UNILA.

Mayliana,E., Sofyan. (2013). Penerapan Accelerated Learning Dengan Pendekatan Savi Untuk Meningkatkan Motivasi Dan Hasil Belajar Kompetensi Menggambar Busana. Pascasarjana Universitas Negeri Yogyakarta.Jurnal Pendidikan Vokasi: Vol 3, Nomor 1, Februari 2013.

Meier, Dave. (2004). The Accelerated Learning Handbook. (Terjemahan Rahmani Astuti). New York: McGraw-Hill. (Buku asli diterbitkan tahun 2000)

Mukaromah., Bintari., Mubarok. (2012). Hasil Belajar Siswa Pada Materi Protista Akibat Penerapan Model Learning Cycle. http://journal.unnes.ac.id/sju/index.php/ujbe. Diakses Pada Tanggal 24 November 2016.

Mustari,M., Irianto., Susilowati. (2016). Peningkatan Aktivitas dan Hasil Belajar Siswa pada Konsep Energi Panas dan Energi Bunyi melalui Model Learning Cyle (LC) 7E.Antologi UPI Edisi No. Juni 2016

Nurhadi, (2004). Kurikulum 2004 Pertanyaan dan Jawaban. Penerbit PT. Grasindo, Jakarta. Diakses pada tanggal 24 November 2016.

Rachman, A. (2013). Implementasi Model Pembelajaran Learning Cycle $7 E$ Sebagai Upaya Meningkatkan Prestasi Belajar Siswa Kelas XI TITL 2 SMK N 2 Pengasih. Skripsi Program Studi Pendidikan Teknik Matematika UNY.

Sanjaya. (2013). Strategi Pembelajaran Berorientasi Standar Proses Pendidikan. Jakarta: Kencana.

Sugiyono. (2009). Metode Penelitian Pendidikan. Bandung: Alfabeta.

Sumiyati.,Sujana., Djuanda. (2016). Penerapan Model Learning Cycle 7E Untuk Meningkatkan Hasil Belajar Siswa Pada Materi Proses Daur Air.Jurnal Pena Ilmiah: Vol. 1, No. 1 (2016).

Sutrisno., Dwiastuti., Karyanto. (2012). Pengaruh Model Learning Cycle 7E Terhadap Motivasi Belajar Siswa Dalam Pembelajaran Biologi. Seminar Nasional IX Pendidikan Biologi FKIP UNS. Diakses Pada Tanggal 24 November 2016.

Widoyoko, E. P. (2009). Evaluasi Program Pembelajaran. Yogyakarta: Pustaka Pelajar. 